\title{
THE PERFECT KING BEE VISIONS OF KINGSHIP IN CLASSICAL ANTIQUITY
}

\author{
$S$ Van Overmeire (Vrije Universiteit Brussel)
}

This article investigates the portrayal of the king bee by Greek and Roman writers. Their depiction of these creatures was not a scientific one: many aspects of their description were influenced by widespread Greek and Roman ideas on government, while others show even more specific influences from contemporary thinking. At the same time, the hive was used as a model for human society, since bees presented a society that succeeded in living together without stasis (civil strife), in harmony.

Nam ut a minimis ordiamur, apes, quae natura duce coetum et societatem colunt mirumque inter se ordinem servant, uni regi obtemperant, quem non ipsae de turba temere delegerunt, sed ab ipsa natura insignem forma et diademate praeditum acceperunt. ${ }^{1}$

To begin with the smallest things, the bees, which at nature's command practice common life and society and observe a marvelous order among themselves, obey a single king, whom they do not choose rashly from the mob; they take from Nature herself one who is remarkable in form and supplied with a diadem (trans. J Hankins).

\section{Bees and metaphors}

In the eyes of a modern spectator, a beehive probably appears as the place of much nervous activity by many interchangeable creatures, an impression which we can link to our own hectic existence. Yet for a long time these creatures were connected to the divine, unlike ants who were more often judged in negative terms. Only with Milton's Paradise lost did bees become fallen angels, earthly and without will. As such, they could no longer serve as an example to human society. Yet the ancient authors that were so admired by Milton considered bees to be special creatures. Their industrious gathering of nectar connected them with the immortals, and they served as an example of natural virtue. Like birds, trees and oracles, they could predict the future and foretold the rule of several tyrants and

Aurelio Lippo Brandolino 3.87, explaining how the power of kings is found even in nature. 
kings. In their order and harmony, they gave humanity an example of social perfection. $^{2}$

The literary depiction of bees in Classical Antiquity has received modest attention in modern scholarly literature. Several authors investigated Virgil's depiction and the way these insects served as a model for Roman society. Griffin (1979:68) showed that this poet's allusions were complex, because bees not only showed the virtues of ancient Rome, but also its faults: 'The bees presented him with a powerful image for the traditional Roman state, in its impersonal and collective character'. Nadeau (1984:77-80) investigated Virgil, bees and the underlying references to human society, while Polleichtner (2005:115-160) looked at the use of the bee simile in Homer, Apollonius of Rhodos and Virgil, and how the latter used these insects to look at the future of Rome. Johnson (1984:1-22) described how the beehive served as a natural metaphor for the republic. Mayhew dedicated a brief article to the difference between the king of the bees and mother of the wasps and argued against older scholarly literature that saw ideological motives behind the choice of a male ruler. ${ }^{3}$ Morley (2007:462-470) focused on Roman thought, the description of the hive in general and the effects on 'apicultural practice'. He studied the influence of contemporary politics on the Roman (especially Seneca and Pliny) authors' vision of bees. He noticed that these writers liked to compare the hive with a military camp, and investigated the civil wars that they discerned among these insects. Politics and the king bee (most ancient authors believed the ruler was male ${ }^{4}$ ) also make their appearance. However, apart from this one article, these kings have received little attention.

We will concentrate our attention on king bees, their portrayal in ancient literature, and the link of these descriptions with ancient political thinking. Greeks and Romans had their own, in some ways unique, vision on government, on 'legitimate' rulers and their primary virtues. Several of these ideas were widespread within the Mediterranean world, and here it is essential to note that some vision of a perfect king, an autocrat fit to rule by his virtues, can be found among Greek and Roman authors of all periods. ${ }^{5}$ Many other ideas and concepts depended on the specific historical situation. Greek authors from the fifth century $\mathrm{BC}$ wrote much on the polis (city-state) and democracy, while treatises on ideal kingship became ubiquitous in the Hellenistic age. Roman republican thinkers

2 Pliny $H N$ 9.18.55-56; Diodorus Siculus 19.2; Hollingsworth 2001:xii-xiii and 23-24; Beanis 1988:204; Moss 1964:3-6; Borthwick 1991:561; Ramírez 2000:16-17, 23.

3 Mayhew 1999:127-128 and 130-131, also see Mayhew 2004:19-24.

4 Hudson-Williams 1935:2-3; Xenophon is an exception, since his choice of gender varies from one text to another.

5 Kloft 1979:28, 33; Hahm 2005:457-459, 461, 463, 469; Oakley 2006:45-48; in general Anderson 2009:18-19; infra for various examples. 
stressed the excellence of their government, and during the principate most philosophers turned to the virtues of the sovereign.

It is quite possible that political ideas, especially those concerning ancient autocrats, influenced the appearance of the king bee in literature. Like the beehive (supra), they offered an interesting metaphor for human society. For example, love can be seen as a journey, a theory as a building and ideas as food. 'Social organisations are plants' is a metaphor as well. The plant itself is the organisation, a branch is part of it, and the growth of the plant is the development of the organisation. In addition, much of this knowledge is subconscious. ${ }^{6}$ When looking at the ancient portrayal of bees, we should consider the way this process could work in two directions: while the organisation of these insects could be made understandable by using human concepts, they also helped in making the social order comprehensible, and their cooperation was also a natural example that humanity could follow.

It seems plausible to suggest that the conception of the king bee was connected with ideas of human kingship. We know that bees were linked with Zeus, king of the gods, and according to Diodorus Siculus, it was he who gave these creatures their special colour and great resistance to winds and cold, as a reminder of the close bond between them. ${ }^{7}$ It was also a monarch - of the Curetes - who discovered how to harvest their honey. Furthermore, the king bee certainly served as an example for sovereigns in later periods: for several medieval rulers (and Napoleon) they were a symbol of monarchy; the successful reign of Elizabeth and the disasters under her male successors, led to the book of Charles Butler. He saw nature as an example to humanity, and demonstrated that bees work hard and in harmony with each other for the good of their society. It was surely no coincidence that they were led by a queen. ${ }^{8}$

In this article, we will focus on ten Greek and Roman writers who mentioned the king bee, namely Plato, Xenophon, Aristotle, Varro, Virgil, Seneca the Younger, Columella, Pliny the Elder, Dio Chrysostom and Aelian. ${ }^{9}$ We will look at their description of king bees, and we will try to relate this to contemporary political ideas on government. When possible, I will draw examples of contemporary thinking from the works of the authors discussed, to illustrate the fact that they believed in these concepts as well. It should be noted that I will not

Kövecses 2009:4-8 and 10.

Diodorus Siculus 5.70

8 Diodorus Siculus 5.65-66; Ramírez 2000:18; Stephens 2003:3; Horn 2006:5-7; Ransome 1937:91-93.

9 Homer, Apollonius of Rhodos and Epictetus will be briefly mentioned. Hesiod famously connected women and drones, while Semonides drew a parallel between the industrious bee and the good wife. These descriptions are of little relevance here. 
limit myself to kings in a strictly political sense - rather I will look at anyone who appears in the role of ruler. Finally, though attention is focused on bees, I will, in passing, discuss the leaders of wasps as well.

\section{The characteristics of king bees}

In the description of the king bees, we can discern a certain common vision. Most writers believe that these creatures are male, which according to the convincing research of Mayhew (1999:130-131) was not due to ideological reasons. Other physical aspects are of more relevance: Aristotle speaks of two types of king bees, one black and inferior, the other red and of the superior kind, and both are twice as large as the workers. Varro tells us that the best king bees have stripes, while others - the inferior ones - are black of colour. Virgil describes the noble king bee as a beautiful sight, shining as if golden. Seneca believes that the king bees are not only bigger, but also more beautiful, and Columella tells us that they have various shiny colours and are larger than their subjects. One author notes that the king wasp is twice as big as the workers as well. ${ }^{10}$

It is quite easy to connect such a view with prevalent opinion on the characteristics of human rulers. Throughout Antiquity, authors stressed the special nature of these men: it was no coincidence, but the will of the gods that they ruled their subjects - and they not only showed this by signs, but virtue was also clearly visible in physical appearance. ${ }^{11}$ For example, Suetonius tells us of the powerful impression that Augustus made on visitors, and his intimidating eyes. ${ }^{12}$ The rulers themselves further stressed their uniqueness by wearing luxurious, special clothing, while their statues wore emblems that emphasised their bond to the gods. ${ }^{13}$ Authors discussed here believed in the special nature of rulers as well: Nero, for example, had a divine appearance according to Seneca, while Aelian tells us of the beauty of men like Alcibiades, Scipio, Demetrius Poliorcetes or Alexander the Great, all natural-born leaders. ${ }^{14}$

I am aware that there is an empirical explanation for some of this: perhaps the Greek and Roman authors observed the queen bee, and noticed her unusual shape. While this is a valid objection, it is important to note that many authors found it necessary to mention — and exaggerate — this trait. The special colour of

10 Aristotle Hist. an. 5.21; Varro Rust. 3.16.18; Virgil G. 4.91-95; Seneca Clem. 1.19.3; Aelian NA 5.15.

11 Rulers and gods: Herz 2007.

12 Suetonius Aug. 79-80.

13 Xenophon Cyr. 8.1.40-41, 8.3.1 and 13-14; Dio Chrysostom Or. 2.49; Athenaeus 13.566c-d; Smith 1988; Stewart 2003.

14 Seneca Apocol. 4; Columella Rust. 9.10.1; Aelian VH 12.14. 
the king bee, furthermore, seems to be in the eye of the beholder alone. Still, the most interesting example of the special appearance of the king bee is found in Pliny the Elder, who believed that he could be recognised by a spot on his head, which looked very much like a diadem. ${ }^{15}$ This made sense: Greek kings, followed by many Roman emperors, had worn the diadem as a symbol of monarchy since the days of Alexander. ${ }^{16}$ So why would nature be any different?

There are other parallels as well. The king bee sometimes has his own bodyguard, to protect and accompany him. ${ }^{17}$ In this he differs little from the barbarian kings of ancient literature, who had a loyal bodyguard chosen from the population. Unlike tyrants, the king bee had no need to search for external protection against the people. According to several authors, the residences of these insect kings were of a special nature too: Aristotle's king bees were born in separate cells; those of Seneca had the largest chamber, located in a safe and central location within the hive. In the works of Pliny, the palace is located at the bottom, and is both beautiful and big, while Aelian's bees build for their sovereign a large royal residence, separated from the rest by a wall. ${ }^{18}$ It is well known that sovereigns, including the Persians, Lydians, Greek tyrants and Roman emperors, often - if not always - had their palace in a conspicuous location, which stressed their power, wealth and position. ${ }^{19}$ The bees of Classical Antiquity apparently understood the prestige that a central, large and beautiful home conferred on its owner. Aelian goes even further: among worker bees, location is determined by prestige as well: the elders, who form the royal bodyguard, inhabit the regions closest to their sovereign. Again, we can think of the Persian kings or Roman emperors: eminent citizens often found a place at their court. ${ }^{20}$ Since wealth had no meaning within the hive, age and the honour of being a part of the king's guard helped determine social status. The author further emphasised how these creatures are superior to men like Cyrus the Older and Younger, who were proud of the palaces and gardens they themselves erected. The population of the hive is more than happy to voluntarily construct a large home for their king. ${ }^{21}$ We will soon discover why.

Thus far, we have seen how both king bees and human monarchs are by nature different from those they rule, a distinction further emphasised by a royal

15 Pliny NH 11.16.50-51.

16 Ritter 1965; Smith 1988:34-37.

17 Aelian NA 1.59; Pliny NH 11.17.52-54. The description of other writers concerning this protection is of a more general nature.

18 Aristotle Hist. an. 5.21; Seneca Clem. 1.19.2; Pliny NH 11.12.29; Aelian NA 1.59.

19 Dio Chrysostom, Or. 2.34 and 37-40; Xenophon Cyr. 7.5.56-57; Nielsen 1994:35-51, 63 and 94-95; Royo 1999; Winterling 1999:67.

20 Xenophon Cyr. 8.1.6; Spawforth 2007.

${ }^{21}$ Aelian NA 1.59; also Xenophon Cyr. 8.4.3. 
bodyguard and palace. Do they have other aspects in common as well? According to the ancients, bees are fully dependent on their kings. Without their guidance, the hive is abandoned, and society plummets into anarchy. In a similar way, wasps search for a king before they even start building their nest. ${ }^{22}$

This link between authority and order within society can be related to contemporary ideas. As Aristotle put it — and few seemed to disagree - authority was inevitable in any society, and while some were destined to rule, others had to follow. For every flock there was a shepherd, and leadership formed an essential part of civilization. This explains why Odysseus found no kings among the Cyclopes: these creatures had no organised social order. ${ }^{23}$ And though many Greek cities were ruled by oligarchies or democracies, philosophers still believed that kingship was natural both to early civilizations and the barbarians, who seemed incapable of living under any other type of government. ${ }^{24}$ Xenophon says that a chain of command is an essential element of human society. This aspect is easier to discern in monarchies, where everyone obeys one man, the sovereign. In his Cyropaedia, furthermore, Artabazus makes an explicit comparison between Cyrus and the king bee: both are born to rule. And since the king bee is essential for order within the hive, his subjects willingly obey their sovereign. Cyrus had not only conquered an empire for his people, but would reorganise their entire society. Clearly, this ruler was as necessary for social order within his own civilization as the king bee in his. Thus, Artabazus believed it was in the best interest of the Persians to follow the example of nature, and give Cyrus their loyal obedience. ${ }^{25}$ Hellenistic thinkers emphasised the crucial role of the king in the cosmic order, as did Roman authors. ${ }^{26}$ In the first century AD, Seneca the Younger drew the (old) parallel between the state and body. The state and its people were subject to their emperor, just as the body was controlled by the soul. He too stresses that without their sovereign, countries fall and chaos takes over. Dio Chrysostom tells us that three types of government exist, but only monarchy is practical. The role of the king bee within the hive can thus be linked with ideas concerning the need for authority, and many authors believed an autocrat could help retain this order. ${ }^{27}$

Here, Varro is more specific: he draws a comparison between the society of bees and man, and believes that both are ruled by one rex (king). So if a competing

22 Aristotle Hist. an. 5.23; Virgil G. 210-218; Seneca Clem. 1.19.2; Pliny NH 11.18.55-56; Aelian NA 1.11.

23 Aristotle Pol. 1.2.8; McGlew 1993:54.

24 Aristotle Pol. 3.9.3-4 and 7-8.

25 Aristotle Pol. 1.2.8; Xenophon Cyr. 5.1.24 and 8.1.4. Possibly, the Persians compared themselves to bees (Brock 2004:254), which would give an extra dimension to the parallel.

26 Balot 2006:271-276.

27 Seneca Clem. 1.3.5 and 1.4.1-2; Dio Chrysostom Or. 3.45-47. 
black king bee causes trouble and tries to start a rebellion, the best course of action is to kill him. It is difficult not to relate this to both common ideas on kingship and the author himself, who lived during the very turbulent years of the late republic, and died when one man had brought peace to the Roman world. A princeps (head of state, emperor) had taken over government in rule, replacing the many, and by doing so he had ended the civil wars. When man looked at nature, he saw bees acting in the same way. ${ }^{28}$

Nor would the hive desire anyone but its monarch as a ruler: the good government of the king bee was essential to the ancient writers. According to them, these rulers either have no sting, or never use it. For a king of such vast multitudes, cruelty was not considered fitting, and everywhere we find the king bee reigning over his realm in a beneficent way. ${ }^{29}$ Virgil tells us that even the eastern barbarians do not respect their kings as much as the bees do: they honour him, and thanks to him, there is peace - without him, all is lost. ${ }^{30}$ So their rule is benign, with the common good in mind. Because of this they are loved by their subjects, and can count on both the obedience and love of their subjects. This can again remind us of the barbarian kings: while they are autocrats, they rule with their subjects in mind, which is why the royal bodyguard, like that of the bee king, is composed of their own population. ${ }^{31}$ Yet beneficent rule is also one of the general characteristics of the ideal human king: this sovereign considers his government as a glorious service to his people. He enjoys giving benefactions, and because of this he can count on the willing, not forced, obedience of the population. The ideal king also forms a contrast with the tyrant. This man rules with only his own interests at heart and is hated by his subjects. Because of this, he needs a large bodyguard of foreigners to guard him. ${ }^{32}$ Descriptions of these rulers go back to Classical Greece. While the good king is compared to a shepherd, who takes care of his herd, the tyrant resembles a wolf. ${ }^{33}$

Since the king bee reminds the reader of the ideal king, he is an example to human rulers, and contrasts with the greed and cruelty of tyrants. Aelian makes this explicit: if a king bee ever leaves his post, his subjects bring him back, while

28 Varro Rust. 3.16.6, 18.

29 Plato Plt. 301d-e; Xenophon Cyr. 5.1.24; Aristotle Hist. an. 5.21; Seneca Clem. 1.19.3; Columella Rust. 9.10.1; Aelian NA 1.60.

30 Virgil G. 4.90-95 and 210-218.

31 Aristotle Pol. 3.9.3-4.

32 Xenophon Ages. 8.4, Cyr. 1.6.24-27 and Mem. 4.12; Aristotle Pol. 3.2.5, 3.5.4, 3.7.5, 3.11.10-12, 4.2.2, 4.8.3, 5.8.6; Seneca Clem. 1.8.1, 1.11.4, 1.13.1 and 1.26.4; Dio Chrysostom Or. 1.22-24, 3.116 and 62.3-4; Aelian VH 2.20, 6.11, 7.20, 9.1, 12.13 and 13.37; Kloft 1979:33; Brock 2004:247-249; Hahm 2005:459; Balot 2006:141-142.

33 Plato Resp. 566e-569c and Leg. 302e; Aristotle Pol. 4.8.3 and 5.8.2; Dio Chrysostom Or. 4.45; Brock 2004:248-249. 
tyrants such as Peisistratus or Dionysius are driven away for breaking the laws and not showing the technê (art) of kingship. Unlike the king bee, they did not love and protect their subjects; like great rulers, the king bee is obeyed voluntarily by the people. The wasps too obey a monarch, who has no sting, and is benign in nature. How despicable compared to this, Aelian asks us, are tyrants like Dionysius, Clearchus or Nabis who trust in the sword? ${ }^{34}$

The appearance of the king bee, combined with the willing obedience of his subjects, also forms a natural model for autocrats. In an oration of Dio Chrysostom, where he makes Diogenes comment on various aspects of Alexander's behaviour, the philosopher stresses the superiority of natural emblems of kingship. Tiaras and purple clothing are useless, compared to the emblem of the king bee, who is obeyed and protected, even though he has no sting. ${ }^{35}$ Meanwhile Alexander, a descendant of Hercules, is forced to protect himself with weapons. Thus bees are utilised to point Alexander, Trajan (who is the target audience of several speeches) and the reader in general to greater things: the true king does not differ from others in clothing, weaponry or other futilities - but he does excel in virtue. And since he is the best, he is obeyed. ${ }^{36}$ Though he does not go into detail, Epictetus seems to make the same point: unlike an arrogant man in his audience, the king of the bees has the signs of leadership, and because of this he is obeyed by his subjects. ${ }^{37}$

\section{The king bee as a democratic leader or warlord}

The portrayal of the king bee by Plato, Aristotle and Xenophon shows some interesting aspects, that can be better understood by the consideration that they lived in a world of independent city-states. In his Statesman, Plato draws a comparison between the king bee and human rulers. Nature proves to be superior to mankind: in the hive, one individual is born with clearly superior qualities, a natural king to his subjects. Humans are less fortunate, and a Greek (philosopher) king is yet to be born. Why? Plato's distrust of democracy and contemporary society is well known, and these are, naturally, to blame. The Greek cities all have their own, specific downsides, which make the birth of a real king, capable of

34 Aelian NA 1.10-11, 5.15; for a more objective and positive appreciation of, for example, Dionysius I and Nabis, see Caven 1990 and Cartledge \& Spawforth 1989:67-77.

35 Apparently Dio Chrysostom disagrees (or is unfamiliar) with Pliny the Elder, according to whom the king bee had the emblem of a diadem around his head, exactly like a human sovereign (supra).

36 Dio Chrysostom Or. 4.24-25, 4.60-63 and 4.66-67, also 62.1; Swain 2002:80.

37 Arrian Epict. Diss.3.22.99. 
ruling men, impossible. Only a perfect society, along the lines suggested by Plato, will be able to educate rulers that can rival the king bee. ${ }^{38}$

In Xenophon's Oeconomicus, the author discusses in some detail how the Persian king supervises his troops, sends emissaries to foreign lands or inspects the land. A good king like Cyrus the Younger, who did his very best in these royal tasks, had many thousands joining him. This, according to 'Socrates', is proof of his excellence. As a further example of good organisation, he tells us how the hegemon (leader) of the bees does not work, but supervises. When the need for founding a colony arises, he selects a leader (oikistes) for this task. Not only the use of the term hegemon, but the idea that oikistai had to be selected for founding a new hive, reminds us of the Greek poleis. ${ }^{39}$ We should also note that in the Oeconomicus the ruler of the bees is a woman because of literary considerations: our author wanted to draw a parallel with the wife of Isomachus. ${ }^{40}$ This description, furthermore, stands in stark contrast with the Cyropaedia, where Xenophon concentrates on the monarchy of bees, and the natural loyalty of the insects.

Equally interesting is Aristotle, who gives an extensive survey of the lives and habits of the bees, and believes that a hive is inhabited and controlled by multiple kings. In fact, and unlike the other writers, he believes that bees cannot survive when there is only one leader, while a mass of rulers leads to the downfall of bee society as well: this causes the emergence of factions and chaos. It is hard not to think of contemporary Athens and its government when Aristotle makes these remarks. ${ }^{41}$ While this philosopher believed in democracy, unlike his tutor Plato, this form of rule had to be of a moderate form. ${ }^{42}$ According to Plato and Aristotle, Athens was plagued by demagogues, who weakened the polis. Likewise, the democratic beehive was threatened by problems of stability as well, and only when bees succeeded in controlling the number of rulers, could they enjoy a secure government. Contemporary belief, and those Aristotle developed himself, obviously influenced this vision of government within the hive. His ideas influenced his portrayal of the bees, and (though this is not made explicit) Aristotle also presented the Athenians with a warning from nature: follow the golden mean. ${ }^{43}$

38 Plato Plt. 301d-e.

39 Xenophon Oec. 4.5-8, 4.16-19 and 7.32; Graham 1964: chapter 3.

40 Pomeroy 1984:104.

41 Aristotle Hist. an. 5.22. Caution is advised: the most important role of these multiple rulers was reproduction (Davies \& Kathirithamby 1986:63).

42 The well educated part of the citizen body, or - in his ideal city-state - the middleclass, should exercise power: Balot 2006:248, 258, 261-262 and 264; Lintott 2000:155 and 159-161.

43 Depew 1995:162 notices that it is wrong to think that Aristotle only speaks metaphorically about animals as political creatures. Of course, this is not the point I am 
The organised nature of bees also caused writers to tie them to soldiers and battles. At the dawn of Greek literature, Homer presented their exodus from the nest as comparable to that of the Greeks, when they leave their camp to do battle. ${ }^{44}$ The Hellenistic poet Apollonius of Rhodos linked king Amycus and his soldiers with these insects. When he is killed, the Bebrycians flee in all directions, like bees that are smoked out of their nest. ${ }^{45}$

Varro compares bees and soldiers quite extensively. Their hive and organisation are also comparable to a military camp, and their leaders give commands with their voice, as if by trumpet. When the insects are ready to fly, they make the same noise as soldiers leaving their camp. Their kings lead them in all things, and are served loyally. When he is fatigued, they run to his rescue. ${ }^{46}$ It is difficult not to relate this description to the author and his life. Warfare was an important aspect of Roman society, ${ }^{47}$ and a comparison between the fights of bees and battles of men comes naturally. That their king leads them in all matters, including warfare, is natural as well: rulers were expected to be great warriors, capable of conquering and maintaining an empire. ${ }^{48}$ Varro could have drawn such ideas from familiar Greek and Roman political thought. ${ }^{49}$ Virgil's Georgica links bees with warfare and the chaos of the late republic. He describes a clash between bees, who have gathered around their monarch and his praetoria (guard). Battles between their kings are a common sight; and the better leader naturally conquers and rules alone. Like Octavian, the good king bee is better in both peace and war. His victory is desired by the gods. ${ }^{50}$

Columella was familiar with both authors, and he tells us that, before leaving, bees make the sound of an army preparing to march. Their fights with other swarms are almost civil wars. ${ }^{51}$ These authors were familiar with warfare, an endemic problem of human history, and the Romans, especially Varro and Virgil, knew of the terrors that civil war brought with it as well. Both these phenomena helped to comprehend the bees. Even in nature, battles were inevitable - but

trying to make: this is an investigation of the influence of the metaphorical element on the description of bees and their kings.

44 Homer Il. 2.87-93.

45 Apollonius of Rhodos 2.177-182.

46 Varro Rust. 3.16.8 and 30.

47 Balot 2006:146-147; Eckstein 2008 emphasises that all ancient Mediterranean states thirsted for war.

48 Xenophon Ages. 5.3 and 6.1; Aristotle Pol. 5.9.13; Dio Chrysostom Or. 1.27.

49 For example Cicero Deiot. 1.26 and Leg. Man. 28.

50 Virgil G. 4.67-87 and 90-95; Nadeau 1984; for bees in the Aeneid, see Polleichtner 2005:138-149; Kingsbury 1956:400 considers such passages 'literary artistry designed for the reader's pleasure'. It is rather more than this.

51 Columella Rust. 9.4-5. 
according to Virgil and Columella, the good king would triumph and continue his benevolent rule.

\section{Beneficent kings of insects and emperors of men}

Earlier, we noted how the ancients believed that the king bee ruled his subjects benevolently, as nature had intended. While writers such as Aristotle give a general account of the bees, others focus their attention on this theme, and not a description of the habits of bees, or their warfare. The writers discussed below lived under Roman rule, and Roman concepts are reflected in their work.

Seneca is the most obvious example. He was employed by Agrippina as a teacher for her son Nero, and when the latter took power, Seneca advised the young emperor together with Burrus. It was in the early days of Nero's government that Seneca wrote a treatise for his former pupil, called the De Clementia. The work draws inspiration from various earlier works, including Xenophon's Cyropaedia and Hellenistic works on the ideal king. ${ }^{52}$ In it, Seneca tries to convince Nero that the primary duty of a ruler is clemency. ${ }^{53}$ It is the job of an emperor to be above reproach, to rule for the good of his subjects and thus he should - whenever possible - use his great power for forgiveness. The great power of kings and principes makes their benefactions possible. ${ }^{54}$ An important example of such behaviour is Nero's forerunner Augustus, who learned the true way of government after the civil wars, forgiving even those that conspired against him. Seneca's preference for this example has to do both with the contemporary admiration for this emperor, and Nero's accession speech, written by the philosopher according to Suetonius, in which he promised to follow the example of the divine Augustus. ${ }^{55}$ Yet nature too shows us the powers of a ruler, and how to use them. Bees are ruled by a king, who occupies a central and secure room in the hive. Although he is bigger and more beautiful than his subjects, he has no sting. This shows that nature did not intend him to be cruel — and the author specifically mentions that great kings should follow this example. Their job is to lead their people well, and because of that, their bees serve them. Nature shows the mighty how they should employ their command. ${ }^{56}$ Worth mentioning is the Apocolocyntosis Divi Claudii, probably written by Seneca as well. Again, we find hopes for a Golden Age under the young Nero, and when Mercury begs Clotho to

\footnotetext{
52 Griffin 1987:78.

53 Griffin 2002:333-334.

54 Seneca Clem. 1.1.1-4, 1.2.1, 1.3.3 and 1.5.2-3-7; Inwood 2005:230.

55 Seneca Clem. 1.9.7, 1.10.1 and 1.11.1-2; Suetonius Nero 10 for the speech.

56 Seneca Clem. 1.19.2-3.
} 
let Claudius die, so that a better emperor can take his place, the god quotes Virgil, talking about the king bees: Dede neci, melior vacua sine regnet in aula. ${ }^{57}$

Pliny naturally gives a detailed description of bees in his Naturalis Historia. He too stresses the way these insects depend on their benevolent king. Further specifics are given: several kings are born in the hive, and only the best is chosen by suffragium (election) to rule over the inhabitants, while the others are killed. They are honoured and supported by a group of equals (in age), and have both guards and lictors. ${ }^{58}$ Here, as elsewhere, Pliny uses his knowledge of human rule for describing the king bee. Contemporary ideas of the role of the Roman princeps are obvious: while they rule supreme, they still serve the people and are - or should be - chosen by acknowledgment of the curia (senate). Pliny was a senator, and thus he envisioned a group of pares (equals, that is to say senators) and lictors accompanying the kings. It was important to Pliny to show that even these natural kings, literally born for the task at hand and in possession of all symbols of kingship, still needed the help of their equals and support of the people. His public, which consisted mostly of eminent and rich civilians, certainly agreed with this analysis. ${ }^{59}$

Columella wrote books on agriculture, and the keeping of bees was part of the farmer's occupation. Thus his book is of a more general nature, yet political ideas certainly make an appearance. He describes the bees as plebs (common people) in need of a ruler. Uttering a Roman wisdom, he tells us that neither king bees nor humans rulers tolerate competitors, and part of the population might decide to depart under their sovereign. ${ }^{60}$ Naturally, this is something a beekeeper cannot allow, so it is best to kill one monarch when mixing the people of several 'hives'. The beekeeper should let the elder live, else part of the bees will have to tolerate a younger ruler. The death of an old sovereign can bring chaos, but a new leader can be chosen from a grouping where there are several. ${ }^{61}$ This too reminds us of Rome in the first century: like old senators, the elder bees did not like obeying a young sovereign. The disorder after the death of the king, and the choice between multiple candidates, might refer to Rome as well: is it a reference to the civil wars that erupted after the death of Caesar, or an allusion to the turmoil that followed the murder of Caligula?

57 'Kill him, so that a better one can rule in an empty court'. Seneca Apocol. 3-4, the quote is from Virgil G. 4.90 .

58 Pliny $N H 11.16 .50-51$ and 11.17.52-54.

59 See Morley 2007:467, the beehive as a well organised and 'constitutional' monarchy.

60 Columella Rust. 9.9.1-2 ; Roman wisdom: Tacitus Ann. 13.17, also Homer Il. 2.204-205.

61 Columella Rust. 9.11.2. 
Finally, we turn again to Virgil, for one last remark. He tells us not only how the good and bad king (respectively Octavian and Antony ${ }^{62}$ ) differ from each other in physical appearance, but that the subjects resemble their sovereign. This too refers to an idea current in Greek and Roman thinking: the rulers perform an exemplary function, and a good monarch will show his behaviour to be virtuous and righteous, thus creating a precedent for the population to follow. Again, this thought appears among several of the writers discussed here, and is used both to describe bees - among them too, this phenomenon exist - and reflects back on the current political situation. Octavian would have to show his virtues, and Suetonius tells us how Augustus did his best as an example to the people. ${ }^{63}$

\section{Conclusions}

The social organisation of insects has fascinated poets and writers throughout the centuries. Greeks and Romans especially admired bees, creatures that had a special connection with the gods and could predict the future. In addition, these creatures apparently lived in a society, under the authority of kings, fighting battles against other hives. This fascinated a variety of ancient authors, who wrote of bee society and the sovereigns under whose authority these insects diligently gathered their honey. Here, we took a look at the portrayal of the king bee in Greek and Roman literature, and how we could relate this to ancient political ideas and concepts.

It quickly becomes clear that political background exercised considerable influence on the description of these insects. Like kings, they had a bodyguard and royal palace. Their appearance set them apart from mere workers, and they were essential to the functioning of society. Furthermore, similar to the ideal human king, the king bee was beloved by his subjects for his just and beneficent rule. Thus human concepts became a way to make bee society comprehensible. Sometimes, the king bee was fitted into an even more specific role: that he served as an example of a beneficent leader during the principate might be easy to guess, but his role as a democratic leader or warlord among earlier authors might be more surprising. In his benevolent aspect, the ancient authors often compared the king bee with human rulers, and he became a model to the sovereign: avoid cruelty and win the respect and obedience of your people with fine deeds.

Naturally, political thought was not the only or decisive element in these descriptions. The ancients certainly observed bees as well, but to comprehend

\footnotetext{
$62 \quad$ Nadeau 1984:77-78.

63 Virgil G. 4.91-95; Cicero Fam. 1.9.12, to Lentulus; Xenophon Cyr. 8.1.30 and 8.8.5; Seneca Clem. 1.19.8; Suetonius Aug. 34, 64 and 72.
} 
them, they decided to use concepts with which they were familiar. ${ }^{64}$ All this is the metaphorical aspect of the portrayal of the king bee: terms and concepts from a familiar domain were used to make more difficult aspects of life comprehensible. Still, the portrayal of the king bee was not merely a subconscious process: these authors also hoped to influence their readers, and with their description of this insect society they provided mankind with a natural example of their choice. Their ideal of society was confirmed in nature. ${ }^{65}$

\section{BIBLIOGRAPHY}

Anderson, G 2009. The personality of the Greek state. JHS 129:1-22.

Balot, R K 2006. Greek political thought. Oxford: Blackwell.

Beanis, I C 1988. Insects and other invertebrates in Classical Antiquity. Oxford: University of Exeter Press.

Borthwick, E R 1991. Bee imagery in Plutarch. CQ 41:560-562.

Brock, R 2004. Xenophon's political imagery. In Tuplin C (ed.), Xenophon and his world, 247-257. Stuttgart: Franz Steiner Verlag.

Cartledge, P \& Spawforth, A 1989. Hellenistic and Roman Sparta: A tale of two cities. London / New York: Routledge.

Caven, B 1990. Dionysius I: War-lord of Sicily. New Haven / London: Yale University Press.

Davies, M \& Kathirithamby, J 1986. Greek insects. London: Duckworth.

Depew, D J 1995. Humans and other political animals in Aristotle's History of animals. Phronesis 40:156-181.

Eckstein, A M 2008. Rome enters the Greek East. Oxford: Blackwell Publishing.

Farber, J J 1979. The Cyropaedia and Hellenistic kingship. AJP 100:497-514.

Graham, A J 1964. Colony and mother city in ancient Greece. Manchester: University Press.

Griffin, J 1979. The fourth Georgic, Virgil, and Rome. G\&R 26:61-80.

Griffin, M T 1987. Nero. The end of a dynasty. London: B T Batsford Ltd.

Griffin, M T 2002. Political thought in the age of Nero. In Croisille J-M and Perrin Y (eds.), Neronia VI: Rome à l'époque néronienne, 325-337. Brussels: Latomus.

Hahm, D E 2005. Kings and constitutions: Hellenistic theories. In Rowe C \& Schofield M (eds.), The Cambridge history of Greek and Roman political thought, 457-476. Cambridge: University Press.

${ }^{64}$ For bees, ancient science and politics: Morley 2007:462 and 465-466.

65 In a similar way, ancient biographers actively chose specific dicta, namely those that they believed illustrated the 'character' of an emperor (Laurence \& Paterson 1999:193). 
Hankins, J 2009. Aurelio Lippo Brandolini: Republics and kingdoms compared. London: Harvard University Press.

Herz, P 2007. Emperors: Caring for the empire and their successors. In Rüpke J (ed.), A companion to Roman religion, 304-316. London: Blackwell Publishing.

Hollingsworth, C 2001. Poetics of the hive: The insect metaphor in literature. Iowa: University of Iowa Press.

Horn, T 2006. Bees in America: How the honey bee shaped a nation. Lexington: University Press of Kentucky.

Hudson-Williams, T 1935. King bees and queen bees. CR 49:2-4.

Inwood, B 2005. Reading Seneca: Stoic philosophy at Rome. Oxford: University Press.

Johnson, W R 1984. Vergil's bees: The ancient Romans' view of Rome. In Patterson A (ed.), Roman images, 1-22. Baltimore: Johns Hopkins University Press.

Kingsbury A 1956. The hero is a bee. CJ 51:396-401.

Kloft, H 1979. Ideologie und Herrschaft in der Antike. Darmstadt: Wissenschaftliche Buchgesellschaft.

Kövecses, Z 2009. Metaphor: A practical introduction. Oxford: University Press.

Laurence, R \& Paterson, J 1999. Power and laughter: Imperial dicta. PBSR 67:183-197.

Lintott, A 2000. Aristotle and the mixed constitution. In Brock R \& Hodkinson S (eds.), Alternatives to Athens: Varieties of political organisation and community in Ancient Greece, 152-166. Oxford: University Press.

Mayhew, R 1999. King-bees and mother-wasps: A note on ideology and gender in Aristotle's entomology. Phronesis 44:127-134.

Mayhew, R 2004. The female in Aristotle's biology: Reason or rationalization.

Chicago: University of Chicago Press.

McGlew, J F 1993. Tyranny and political culture in Ancient Greece. Ithaca: Cornell University Press.

Morley, N 2007. Civil war and succession crisis in Roman beekeeping. Historia 56:462-470.

Moss, B R 1964. ... and the bees. Pegasus 1:2-7.

Nadeau, Y 1984. The lover and the statesman: A study in apiculture. In Woodman T \& West D (eds.), Poetry and politics in the age of Augustus, 59-82. Cambridge: University Press.

Nielsen, I 1994. Hellenistic palaces: Tradition and renewal. Aarhus: University Press.

Oakley, F 2006. Kingship: The politics of enchantment. Malden: Blackwell Publishing. 
Polleichtner, W 2005. The bee simile: How Vergil emulated Apollonius in his use of Homeric poetry. GFA 8:115-160.

Pomeroy, S B 1984. The Persian king and the queen bee. AJAH 9:98-108.

Ramírez, J 2000. The beehive metaphor: From Gaudí to Le Corbusier. London: Reaktion Books.

Ransome, H M 1937. The sacred bee in ancient times and folklore. London: George Allen \& Unwin.

Ritter, H W 1965. Diadem und Königsherrschaft. München/Berlin: C H Beck'sche Verlagsbuchhandlung.

Royo, M 1999. Domus Imperatoriae: Topographie, formation et imaginaire des palais impériaux du Palatin. Rome: École Française de Rome.

Smith, R R R 1988. Hellenistic royal portraits. Oxford: Clarendon Press.

Spawforth, A J S 2007. The court and court society in ancient monarchies. Cambridge: University Press.

Stephens, S A 2003. Seeing double: Intercultural poetics in Ptolemaic Alexandria. Berkeley: University of California Press.

Stewart, P 2003. Statues in Roman society. Oxford: University Press.

Swain, S 2002. Dio Chrysostom: Politics, letters, and philosophy. Oxford: University Press

Winterling, A 1999. Aula Caesaris. München: R Oldenbourg. 